Scholarship Repository

University of Minnesota Law School

Articles

Faculty Scholarship

2013

\title{
It's the Law Schools Stupid! Explaining the Continuing Increase in the Number of Lawyers
}

Herbert M. Kritzer

University of Minnesota Law School, kritzer@umn.edu

Follow this and additional works at: https://scholarship.law.umn.edu/faculty_articles

Part of the Law Commons

\section{Recommended Citation}

Herbert M. Kritzer, It's the Law Schools Stupid! Explaining the Continuing Increase in the Number of Lawyers, 19 INT'L J. LEGAL PROF. 209 (2013), available at https://scholarship.law.umn.edu/faculty_articles/ 4.

This Article is brought to you for free and open access by the University of Minnesota Law School. It has been accepted for inclusion in the Faculty Scholarship collection by an authorized administrator of the Scholarship Repository. For more information, please contact lenzx009@umn.edu. 


\title{
IT'S THE LAW SCHOOLS STUPID!
}

\section{EXPLAINING THE CONTINUING INCREASE IN THE NUMBER OF LAWYERS}

\author{
Herbert M. Kritzer*
}

\section{INTRODUCTION}

How are we to understand the phenomenal growth in the number of legal professionals in many countries around the world? In Common Law countries the gatekeeper to the legal profession was, until sometime in the $20^{\text {th }}$ Century the profession itself. This gatekeeping was accomplished largely through apprenticeship which was either formally or informally necessary to become qualified. As described by Richard Abel the apprenticeship often involved forgoing most, if not all, income which provided a further barrier to entry (Abel 1988, p. 35-62,139-64). While outside the U.S. apprenticeship has not entirely disappeared, surviving in forms such as traineeships,

pupilage, and articles, by the mid to late $20^{\text {th }}$ Century universities had largely become the primary training ground for those seeking to enter the profession (Abel 1986, p. 10-11; Abel 1988, p. 270-81; Kritzer 1991, p. 547-49). Importantly, while the profession had, and arguably continues to have, an incentive to "control the production of producers," the universities generally have no such incentive. Given the shift of control from the profession to the educational establishment, one must focus on that educational institutions to arrive at an understanding of why there has (or has not) been a substantial growth in the number of law graduates and lawyers.

Universities have two primary incentives, revenue and prestige. ${ }^{1}$ These incentives will tend to work in opposite directions, with the former tending to push for greater numbers and the latter for restriction in numbers. However, in an educational system with a strong pre-existing prestige ranking, those institutions lower down in the hierarchy will be driven largely by the revenue incentive, often turning away only those who are manifestly unprepared, if even those. The institutions concerned about prestige will focus on a combination of qualifications and selectivity, and would be expected to allow enrollments to increase only as long as the desired

\footnotetext{
* Marvin J. Sonosky Chair of Law and Public Policy, University of Minnesota Law School. BA Haverford College; Ph.D. University of North Carolina at Chapel Hill.

This paper was originally prepared for presentation at the workshop on "Too Many Lawyers? Facts, Reasons, Consequences and Solutions,” International Institute for the Sociology of Law, Õnati, Spain, April 19-20, 2012. My thanks to Masayuki Murayama, Daniel Foote, Avrom Sherr, and Hazel Genn for sharing with me their insights as to developments in their own countries. Tamar Moustafa, James Foster, and Tracy Lightcap provided helpful comments and suggestions. Thanks also to David Clark for sharing with me a forthcoming chapter comparing legal education around the world and to Brian Tamanaha for sharing his book manuscript prior to its actual publication.

${ }^{1}$ Regarding the revenue incentive and how that can be important at highly selective institutions, see Tamanaha (2012a, p. 63-64). Some institutions might have as a primary motivation either a religious or ideological perspective, and for those revenue and prestige might be less important.
} 
balance can be maintained. Some very prestigious schools can attract large numbers of very highly qualified applicants and have high enrollments, while other schools toward the bottom in prestige may have large enrollments because they are at best minimally selective in their admissions policies. $^{2}$

The universities (or stand-alone law schools) represent the supply side of the production of producers. However, that is only half of the equation. The other half is the demand side: students seeking legal education. Students can have a range of motivations: ${ }^{3}$ potential income, social status, the prospect of interesting and satisfying work, and/or service to a community or an ideology. ${ }^{4}$ The decision about whether to seek a legal education will depend on how strong that motivation is, the perceived likelihood of succeeding with regard to the motivation, and the costs of obtaining the education.

In the sections that follow, I will consider both the supply side and the demand side of the legal education/training equation. With regard to the supply side, I will focus largely in what has changed over the last 30-50 years, and the factors that might account for these changes. With regard to the demand side, I consider the issues confronting potential law students as they consider their motivations, prospects of achieving those motivations, and the costs of obtaining the necessary education and training.

\section{THE SUPPLY SIDE}

\section{The Law School and Law Student Explosion}

In 1963 in the United States, there were 135 ABA accredited law schools enrolling 46,666 students in JD (or LLB) programs; that year a total of 9,638 degrees were awarded by these programs. By the 2011-12 academic year there were 201 ABA accredited schools and JD

\footnotetext{
${ }^{2}$ In fact, Harvard Law School is both ranked at or near the top by most observers and as of 2011 the largest law school in the U.S. with over 1,700 full time students (http://grad-schools.usnews.rankingsandreviews.com/bestgraduate-schools/top-law-schools/law-rankings, last visited February 12, 2012); as an indicator of selectivity, the median LSAT score of entering Harvard students is 173 (http://www.top-law-schools.com/harvard-law-school.html, last visited February 11, 2012). The next largest is the unranked Florida Coastal School of Law with just under 1,700 students; the median LSAT at FCSL is 150 (http://www.top-law-schools.com/florida-coastal-law.html, last visited February 11, 2012).

${ }^{3}$ Motivations may well change during the law school experience (see, for example, Erlanger \& Klegonn 1978; Kahlenberg 1999; Stover 1989), as can the perception of the likelihood of fulfilling the motivation.

${ }^{4}$ My efforts to locate any recent research on the motivations leading students to law school were unsuccessful. A review of empirical research on legal education (Ogloff, et al. 2000, p. 79n12) was similarly unsuccessful in finding research less than 30 years old. The most recent study I found was a doctoral dissertation from 1995 (Waring 1995), which asked respondents (incoming students from seven unnamed law schools) to rate the importance 36 possible reasons for choosing to enroll in law school; unfortunately, the author reduced those items to a set of factors and never provided summary statistics for the individual items. When I contacted the author, he informed me that the data were no longer available.
} 
enrollment had more than tripled to 146,288; the prior year 44,495 JD degrees were awarded. ${ }^{5}$ Thus, enrollment grew by about 100,000 and the number of ABA-accredited schools by 66 . Moreover, the average JD enrollment at an ABA-accredited law school more than doubled, from 345 to 729 . About two-thirds of the 100,000 additional students reflected growth in the number of women pursuing JDs from only 1,739 in 1963-64 to 68,262 in 2009-10 the number of men pursuing JDs grew 74 percent over this period from 44,927 to 78,026. ${ }^{6}$ There was a surge in the number of law schools as the baby-boom generation arrived with the number of schools increasing by an average of two per year from 1965 through 1980; in the last 30 years, there has been about one school added each year although the growth has by no means been steady with 17 schools added in the most recent 10 year period shown in the ABA data.

Figures on enrollments in other countries are harder to find, but there is reasonably good information on the growth in the number of schools with law programs (some called law schools, some called law faculties, and some called law departments). Richard Abel reports that prior to World War II, twelve English Universities offered academic programs of legal education; by 1980-81, this number had grown to 49 including 24 programs in what were then called polytechnics (Abel 1986, p. 10); in 1986-87 there was something over 4,000 law graduates (Kibble 1989, p. 135). From the list shown on the archived website of the now defunct UK Council on Legal Education (UKLE), I count 75 law programs in England and Wales, plus one program in Scotland (out of 11 Scottish institutions with law programs) as well as both of the law faculties in Northern Ireland that offer English law degrees. ${ }^{7}$ A UKCLE 2001 report noted that at that time there were about 10,000 law graduates each year, about 45 percent of whom

\footnotetext{
${ }^{5}$ The last school in the U.S. top award an LLB degree rather than a JD was Yale, and it switched to the JD in 1971 (http://en.wikipedia.org/wiki/Bachelor_of_Laws, last visited June 20, 2012).

${ }^{6}$ All of these statistics are from the ABA Section on Legal Education and Admission to the Bar (http://www.americanbar.org/content/dam/aba/administrative/legal_education_and_admissions_to_the_bar/stats_1.a uthcheckdam.pdf, last visited June 18, 2012). Note that these figures do not include another 46 law schools in California (as of April 2010) that are either accredited by the state (18 schools) or are unaccredited by registered with the state's Committee of Bar Examiners (16 fixed- facility schools, seven correspondence schools, and five distance-learning schools) (http://www.top-law-schools.com/californias-law-school-baby-bar.html, last visited February 10, 2012). I could not find data on the number of students enrolled in these schools albeit based on attempts to take California's "baby bar", required for those enrolled at unaccredited law schools who hope to eventually take the California bar exam, the numbers must be quite low at many of those schools (http://www.toplaw-schools.com/uploads/File/FYLSX_Pass_Rates.pdf, last visited February 10, 2012); this may also be true for most of the state-accredited schools in California (see http://www.protectconsumerjustice.org/2010-california-barexam-pass-rates-by-law-school-2.html, last visited February 10, 2012)]. There are also one or two state-accredited law schools (that do not have ABA accreditation) in Alabama, Massachusetts, and Tennessee [http://en.wikipedia.org/wiki/List_of_law_schools_in the_United_States, last visited June 19, 2012].

${ }^{7}$ See http://www.ukcle.ac.uk/about/reports/baseline/, last visited February 10, 2012; this report also says that there were "over 150 institutions offer[ing] legal education in the UK", but it is not clear how legal education was defined for this purpose. What is unclear is the degree to which the increase from 49 to 75 represents an increase in the number of institutions offering courses in law, or simply an increase in the number offering degrees in law; some former polytechnics might have had courses with the degrees issued through a different polytechnic but after the conversion of polytechnics to universities, institutions started offering their own degrees (my thanks to Avrom Sherr for suggesting this possibility).
} 
were entering the legal profession; ${ }^{8}$ some portion of these graduates were from Scotland and Northern Ireland, but the figure suggests that the number had probably doubled over the prior 15 years.

In 1960 there were six university law schools in Australia (Weisbrot 1989, p. 85); ${ }^{9}$ by 1987 there were twelve. Over a period of a little more than 20 years ending in 2008 the number grew to thirty-one (Prior 2008, p. 14-15). The number of students studying law had climbed to 28,000 (see http://www.alsa.net.au/about-alsa, last visited February 11, 2012), and this number constituted 70 percent of the number of lawyers $(40,000)$ in Australia (Prior 2008, p. 14-15). ${ }^{10}$ The growth in law departments (and presumably in the number of students) needs to be considered as part of broad changes to higher education in Australia. Between 1975 and 1994 the number of universities increased from 19 to 36 and the enrollment in those institutions from 148,000 to 585,000; by 2006 there 40 universities with almost 1 million students, although some of the later growth was in international students (see http://www.acuma.org.au/resource_library/vsu/vsu_impact_study/section03/index.htm, last visited February 11, 2012). This in turn reflects Australia's shift from a system of higher education for the elite to a system directed to the masses (Moodie 2010, p. 4). ${ }^{11}$

Compared to England, and Australia, the provision of legal education in Canada has been relatively stable since the late 1980s (through at least 2002). ${ }^{12}$ The number of law graduates in Canada was steady during that period at about 3,500 per year, 2,500 of whom were "called to the bar" with the other 1,000 pursuing other careers (Brusegard 2004, p. 5). ${ }^{13}$ From 1980 through 2010 no new law schools opened in Canada (Levin \& Alkoby 2012, p. \{1\}); in 2011 a $22^{\text {nd }}$ law school opened in British Columbia (Dodek 2011, p. 245), ${ }^{14}$ and a second new law school is to open in Thunder Bay, Ontario in 1913 (Levin \& Alkoby 2012, p. \{1\}). In fact, for a period of 22 years from 1976 to 1998 the number of first year law students in common law programs remained steady at about 2,000 (Cohen 1998). However, at least in Ontario, there has been some

\footnotetext{
${ }^{8}$ See http://www.ukcle.ac.uk/students/directory/, last visited February 10, 2012.

${ }^{9}$ Wikepedia lists 32 law schools in Australia (see http://en.wikipedia.org/wiki/List_of_law_schools_in_Australia, last visited February 11, 2012).

${ }^{10}$ In 1961 the total number of lawyers in Australia was about 6,600; the figure doubled by 1975, and doubled again by 1986 (Weisbrot 1989, p. 86).

${ }^{11}$ In the 1970s there was a move to make university education more accessible by abolishing university fees; however, due to the take-up rate and the resultant costs, fees were reintroduced in the 1980s (see http://en.wikipedia.org/wiki/Tertiary_education_in_Australia\#After_1972, last visited February 11, 2012).

${ }_{12}$ During the ten year period from 1968 through 1978, four new law schools were started in the common law provinces (Mazer 1989, p. 131n37). There were sharp increases in the number of law students in Canada in the 1960s and 1970s (ibid., p. 127).

13 The number may have grown in the last few years. The Federation of Law Societies of Canada's 2009 Statistical Report (available at http://www.flsc.ca/_documents/2009-Law-Societies-Statistics-C.pdf, last visited February 11, 2012) reports that 3,464 students were called to the bar in 2009. Alternatively, Brusegard's figure may have excluded Quebec as a civil law jurisdiction (about 1,000 students were called to the Barreau du Québec or the Chambre des Notaires du Québec in 2009).

${ }^{14}$ While Dodek refers to their being 22 law schools in Canada, another source I consulted lists a total of 25 (see http://jurist.law.utoronto.ca/lawschl.htm, last visited February 8, 2012).
} 
growth since 1997 with the number of entering students growing from about 1,000 per year to about 1,400 by 2011 (http://www.ouac.on.ca/statistics/law-school-application-statistics/, last visited February 20, 2012). ${ }^{15}$

Germany is a country where universities have long played a major role in preparing legal professionals. ${ }^{16}$ University-based legal education in Germany can be traced back to the $14^{\text {th }}$ century (Korioth 2006, p. 86). In modern Germany preparation for legal practice begins with a university education concluding with a first state examination, which is then followed by practical training similar in some ways to the rotation system used in training physicians in many countries; a second state examination follows the completion of the period of practical training. The university stage is essentially open to all comers meeting the requirements for entrance into a university which is passing the Gymnasium final examination (Abitur); while students might be turned away from their first-choice schools, all are guaranteed a place at one university or another, and studies are free of charge (Korioth 2006, p. 90). The result is large numbers of students studying law: 100,000 across 43 law faculties circa 2003 (Korioth 2006, p. 89), ${ }^{17}$ which is an average of 2,325 per law faculty (compare this to the largest American law school which has about 1,700 students). ${ }^{18}$ The typical student takes the first examination after about 5 years (technically the university course of study only requires four years); it appears that on the order of 50 percent of those who begin law studies ultimately pass the first state examination at the end of university studies. ${ }^{19}$ Circa 2003 , something over 10,000 per year ultimately pass the second state examination (Korioth 2006, p. 89), although for the most recent years for which I could find figures, the number had dropped off by about 10 percent (http://www.brak.de/w/files/04_fuer_journalisten/Jurastudenten2004, last visited February 20, 2012). The number of students starting law studies increased from under 10,000 per year prior to 1983 to on the order of 20,000 per year by the early 1990s (a figure that has been relatively stable; ibid.). ${ }^{20}$

There were only nine law departments in Japanese universities before World War II. By 2005 there were 93 law departments with about 45,000 students starting (undergraduate) law

\footnotetext{
${ }^{15}$ The number of first-year applicants to Ontario law schools increased from about 3,300 to about 4,700 over this period which is virtually the same percentage increase as in the number of entering first-year students.

${ }^{16}$ See Clark (2012) for a discussion of the development of legal training and education in civil law countries. In many countries there were a mix of legal professions, some requiring a university education and some not.

${ }^{17}$ The number had peaked at 112,756 in 1997, and was down to 92,577 in 2010; in recent years, roughly 10 percent of law students in Germany have not been German. These figures are from http://www.destatis.de/jetspeed/portal/cms/Sites/destatis/Internet/EN/Content/Statistics/TimeSeries/LongTermSeries /Education/Content100/lrbil03a,templateId=renderPrint.psml, last visited February 12, 2012.

${ }^{18}$ Korioth (2006, p. 91) notes that one university, Ludwig-Maximilians-Universität Munich had 4,000 students studying law.

${ }^{19}$ I arrive at this figure based on Korioth's observations that about 20 percent (or more) "change their subject or leave the university before taking the First State Examination (p. 90), 10 to 20 percent fail an intermediate examination (p. 95n54), and 30 percent who take the first state examination fail to pass (p. 96).

${ }^{20}$ Some of this increase reflects the unification of Germany. In 1990 about 16,000 students entered law faculties; in 1991 the number jumped to about 21,600.
} 
studies each year (Yoshida 2006, p. 209). ${ }^{21}$ As I discuss below, very few of the eventual graduates of these programs went on to become fully qualified lawyers (bengoshi) because of limits imposed on the number who could pass the National Bar Examination required for entry into the Legal Training and Research Institute (LTRI); ${ }^{22}$ only LTRI graduates are qualified to appear as advocates in court, although many other law graduates perform a range of tasks commonly done by lawyers in the U.S. (Aronson 2012, p. 276; Saegusa 2009, p. 371-72). The system was changed in 2004 with the creation of post-graduate legal education in Japan; 74 new law schools were created to provide this education. The expectation was that a substantial portion of graduates of these programs - possibly 50 percent (Saegusa 2009, p. 393) or even 70 percent (Aronson 2012, p. 274; Tanikawa 2011)_would pass the National Bar examination and enter the LTRI for a 12 month course of study. ${ }^{23}$ However, as things have worked out, the pass rate on the new exam, which started out close to 50 percent has steadily dropped, and was under 25 percent for 2011 (Chan 2012, p. \{19); more importantly, the pass rate varies greatly by law school attended, ranging from 50 percent down to zero-i.e., no graduates of some schools passed (Weiss 2011). ${ }^{24}$ Several of the new law schools have announced plans to close after current students complete their JDs; ${ }^{25}$ how many of the new schools will ultimately survive, particularly those with very low pass rates, is unknown. ${ }^{26}$ It does appear that the low pass rate has served to discourage potential students from applying to one of the new JD programs; the

\footnotetext{
${ }^{21}$ Clark (2012:\{10\}) presents data suggesting that the number of law students actually declined between 1990 and 2009 from 190,000 to 168,000; it is unclear whether the 2009 number is only undergraduates or includes students in the new JD program. It may be that with the requirement of pursuing a second degree, many students who would have pursued an LLB are unwilling to invest the additional time that would be required to obtain the JD, and are pursuing other courses of study.

${ }^{22}$ For many years, only 500 exam takers per year passed; by 2005 the number passing each year had been increased to 1,500 (Yoshida 2006, p. 211).

${ }^{23}$ Under the old system, the JTI course lasted 18 months.

${ }^{24}$ The decline in the pass rate does not simply reflect second and third attempts; the pass rate for first-time exam takers has declined from 48.3\% the first year the exam was given (2006) to 33.0\% in 2010 (Foote 2011, p. 51). Part of the rationale behind the new schools was to encourage persons who had not studied law at the undergraduate level to pursue a legal career by attending one of the new JD schools; however, the bar pass rate for those who had not studied law as undergraduates "has been far lower than for those who studied law at the undergraduate level before entering law school” (id., 52).

${ }^{25}$ The most recent school to announce plans to close is the law school at Meiji Gakuin University (not to be confused with Meiji University); Meiji Gakuin has had trouble filling its class, and its students have not had a lot of success on the LTRI exam (a four percent pass rate in the most recent year). Previously, two other law schools had announced plans to close, Himeji Dokkyo University Law School and Omiya Law School [see http://www.yomiuri.co.jp/dy/national/T120530004820.htm, last visited June 18, 2012]; Himeji Dokkyo had the losest pass rate for the bar exam among the new law schools [see http://www.asahi.com/english/TKY201005280363.html, last visited June 18, 2012].

${ }^{26}$ South Korea has had a system very similar to Japan's (see Kim 2006), and is making a similar shift to postgraduate legal training as preparation for the national bar exam with one important difference: the number of postgraduate law schools and the number of students in those schools will be strictly limited (Ahn 2006, p. 236). Interestingly, as I will discuss below, it appears that the original plan in Japan was to limit the number of schools (Jones 2009, p. 253).
} 
number of applicants has declined from 73,000 the first year the schools were in operation to 24,000 in 2010 (Foote 2011: 52). ${ }^{27}$

Clark (2012, p. \{10\}) provides data on the increase in the number of law students from 1970 to 2009 for several additional civil law countries: 59,000 to 216,000 Italy; 21,000 to 112,000 in Spain (actually down from 160,000 in 1990). In contrast, the growth in France has been minimal, from 158,000 to $170,000 .{ }^{28}$ Clark also shows the growth in the numbers studying law in several Latin American countries, where the increases have been as high as a factor of 10 or more in Brazil, Columbia, and Mexico (id., at $\{13-15\}){ }^{29}$

\section{Explaining the Increased Supply of Legal Education}

Some of the increased number of places for students to study law reflects demand driven by demographics. Two factors that stand out are the number of persons of the right age to start such studies (i.e., the post-war baby boom) and the opening of educational and professional opportunities to women. Some of the increased numbers reflect nation-specific developments such as the unification of Germany. Some of the increased numbers reflect deliberate decisions by governments to widen the scope of educational opportunity; this occurred both in Australia and in Germany.

While demand is a major factor in decisions about supply, one must consider other factors. Central here is finance. In most countries, the bulk of the cost of higher education, including legal education, has been state-funded. In Great Britain, until 1998 universities charged no tuition and students could receive modest maintenance grants to cover living expenses; while tuition increased substantially in Britain after it was introduced, university education continued to be highly subsidized at least through 2011. Effective September 2012 tuition will rise to as much as $£ 9,000$ per year and most of the remaining direct government subsidy for instruction

\footnotetext{
${ }^{27}$ A possible explanation for some of the initial drop-off is that initially a lot of students for the new law schools had been working inside corporations and were attracted by the possibility of becoming qualified bengoshi with the expected pass rate of on the bar exam of 70 percent; when that pass rate did not materialize, this potential constituency declined, or possibly even disappeared. This may have even led to a decline in the overall quality of students in the new law schools (Aronson 2012, p. 274).

${ }^{28}$ Through 2010, those desiring to become a lawyer (abogado or procurador) in Spain only needed to complete a law degree, although other legal professions (e.g., a notary) required passing a qualifying exam (Piñeiro 2012, p. \{2$3\}$ ); as part of the European integration process this changed in 2011, and there are no requirements for additional coursework and an examination (id., at 9).

${ }^{29}$ Moustafa (2010, p. 613-18) tells a very different story about the sharp increase in the number of students studying law in Egypt that began around 1960. According to his analysis, admissions were opened up both to make the universities less elitist and to downgrade the prestige (and income) of the legal profession whose members were antagonistic toward the Nasser regime. The best students who once might have entered the law faculty were drawn to other faculties that were created (e.g., economics and political science) that would lead to secure careers in government service. Moreover, the standards for admission to law faculties fell, resulting in large numbers of students, many of whom were not particularly strong; this in turn led to large numbers entering the legal profession which increased competition for clients and pushed down incomes.
} 
will be replaced with a system of government loans to students; ${ }^{30}$ repayment will be tied to income with the former student required to pay nine percent of any income exceeding $£ 21,000$ per year for 30 years after which any remaining debt is to be forgiven (Hutton 2012). In Germany, education at public universities continues to be tuition-free in most Lander. Canadian universities do charge tuition, but it continues to be modest in comparison to the cost of providing education; for example, the average tuition for law students in 2010-11 was \$4,633 (http://www.statcan.gc.ca/daily-quotidien/100916/t100916a4-eng.htm, last visited February 20, 2012). All but four of the universities in Australia are public; while tuition typically is on the order of $\$ 8,000$ to $\$ 10,000$ per year, this reflects a significant governmental subsidy and Australian students can receive loans that are paid off after graduation based on formulas based on the graduate's income.

While education in most other countries considered above is largely delivered by public universities, in both Japan and the United States private universities play a major role. In Japan, 70 percent of students attend private universities. Both public and private universities charge substantial tuition. For private universities in 2006 tuition averaged about \$13,000 with public universities at about \$8,000 (http://www.japan-press.co.jp/2006/2499/education.html, last visited February 20, 2012).

In the U.S., the split between public and private is the reverse of Japan with 73 percent of students attending public universities; only 16 percent attend private, nonprofit colleges and universities (http://www.usnews.com/education/blogs/the-college-solution/2011/09/06/20surprising-higher-education-facts, ${ }^{31}$ last visited February 20, 2012). At the undergraduate level, public education in the U.S. continues to be highly subsidized by government; average tuition for public 4-year colleges and universities is about \$7,300 compared to $\$ 27,293$ for private institutions (http://chronicle.com /article/Costs-at-4-Year-Private/128201/, last visited February 20, 2012). ${ }^{32}$ While the in the U.S., the public subsidy for university education has generally been declining over the last 30 years, in recent years the decline for public law schools has been especially sharp; in a small number of states the subsidy for law students has all but disappeared, essentially privatizing the school (see Fischer 2010). ${ }^{33}$ The average tuition and fees at public law

\footnotetext{
${ }^{30}$ The UK government continues to provide some direct subsidies for university-based research, but this is based on highly competitive periodic reviews (previously called the Research Assessment Exercise but now rebranded the Research Excellence Framework).

${ }^{31}$ These figures are drawn from The Chronicle of Higher Education's almanac (http://chronicle.com/section/Almanac-of-Higher-Education/536/). In one omits those institutions that grant only two-year degrees, 63 percent of students attend public institutions, 25 percent attend private nonprofit colleges and universities, and 11 percent attend for-profit institutions (percentages do not add to 100 due to rounding; http://chronicle.com/article/For-Profit-Colleges-Grow/128594/, last visited February 20, 2012).

${ }^{32}$ For public institutions, these figures are for students who are residents of the state where the institution is located; for nonresidents, the average is close to $\$ 20,000$. Note also, that these figures do not take into account individualized (usually means-tested) financial assistance received by students.

${ }^{33}$ There is also a phenomenon of formerly private law schools being absorbed by state universities, but remaining private; examples are the former Detroit College of Law which was absorbed by Michigan State (the MSU College of Law website describes it as "becoming affiliated") and Franklin Pierce which was absorbed by the University of
} 
schools for students who are residents of the state funding the institution has risen from \$2,006 in 1985 to \$18,472 in 2009 (medians from \$1,792 to \$16,546). For students who are not residents, the average published tuition at public institutions has increased from $\$ 4,724$ to $\$ 30,413$. This puts the nonresident tuition fairly close to the tuition charged by private law schools which in 2009 averaged $\$ 35,743$ (up from $\$ 7,526$ in 1985). ${ }^{34}$

What about factors related to the interests of the educational institutions? Compared to many other types of professional-level training provided through universities, legal education is relatively inexpensive. It requires relatively minimal facilities beyond lecture halls and libraries (Segal 2011b). It can be delivered to large numbers of students, and the number of students can be increased in ways that are disproportionate to increased costs of providing that education. The facilities faculty need for their own research and writing are relatively modest compared to other disciplines of comparable prestige. To put it crudely, law schools have, or perhaps had, the potential of being a profit center-a "cash cow" (Bourne 2012, p. \{39\}; Tamanaha 2012a, p. 127) — for a university. In the words of one observer of American law schools, "It is one of the academy's open secrets: law schools toss off so much cash they are sometimes required to hand over as much as 30 percent of their revenue to universities, to subsidize less profitable fields" (Segal 2011c). ${ }^{35}$ This is by no means unique to the United States. One possible explanation for the increase in both the number and size (in student counts) of law faculties in England is that the revenue per student (government payment plus tuition through 2011) more than covers the cost of educating the additional students, and the surplus can be redirected to subsidize more costly areas of instruction. $^{36}$

A second factor related to institutional interests is that have a law faculty or law school adds a measure of prestige for an institution. Why, for example, did the University of St. Thomas in Minneapolis/St. Paul decide it needed to have a law school? No one suggested that there was a shortage of places for law students in Minnesota (or nearby areas in surrounding states). The university's explanation was that it was creating a different kind of law school, one that would place an emphasis on values consistent with Catholic social thought; in the words of the school's

New Hampshire. There is also the case of the Dickinson Law School which was absorbed by Pennsylvania State University ("Penn State"), but apparently has maintained a single level of tuition comparable to other private law schools.

34 These figures are from http://www.americanbar.org/content/dam/aba/migrated/legaled/statistics/charts/stats_5.authcheckdam.pdf (last visited February 22, 2012); see also Tamanaha (2012a, p. 107-08).

${ }^{35}$ A number of law schools are not affiliated with universities; Wikipedia lists 18 ABA-accredited, independent law schools (http://en.wikipedia.org/wiki/Category:Independent_law_schools_in the_United_States, last visited March 15, 2012). For these schools, there is no larger institution to seeking to use the law school as a "cash cow."

${ }^{36}$ The subsidy is likely to take the form of covering a disproportionate share of central institutional costs rather than as a transfer payment from one program to another. Another factor in England revolves around how the funding formula used for universities. Disciplines are placed into bands reflecting the costs of education. Law falls in the lowest cost band along with a range of humanities and social science disciplines. Universities are allocated a certain number of students within each band. The demand for law places remains strong, and thus universities who experience a decline in demand for places in the humanities and/or social science seats can normally fill any shortage in the relevant band with law students. 
current mission statement, “The University of St. Thomas School of Law, as a Catholic law school, is dedicated to integrating faith and reason in the search for truth through a focus on morality and social justice” (http://www.stthomas.edu/law/about/mission/default.html, last visited February 22, 2012). The university had received some significant gifts to fund the startup costs for the school, but arguably the larger goal was to increase the institutions prestige regionally if not nationally. Several years after the law school was started, St. Thomas flirted with creating a medical school, which would have further established its bona fides as a major institution, but quickly abandoned that plan (almost certainly due at least in part to the much greater costs involved in starting a medical school compared to a law school).

As noted above, there has been a sharp increase in the number of law faculties in England in the last 25 years. An important development in the history of English higher education was the rebranding of polytechnics and a range of other institutions as universities under the terms of the Further and Higher Education Act 1992; ${ }^{37}$ many of these new universities proceeded to establish degree granting law faculties, and the motivation to do so was probably a combination of the revenue over and above costs that might be produced and a view that a true university should have a law faculty.

As discussed previously, Japan has recently changed educational requirements for those hoping to become bengoshi. As part of the change, planners anticipated that perhaps 20 schools would create post-graduate JD programs (Maxeiner 2003, p. 10), although the relevant authorities chose not to impose any specific limit and to recognize any program that met a set of minimum requirements. As a result, 74 new schools were created, almost all of which were located at universities with existing undergraduate law programs; the decision not to impose an arbitrary limit avoided the potential of having to make difficult political decisions as to which universities would or would not be allowed to have one of the new programs. ${ }^{38}$ Despite the fact that many of these universities had relatively few students who had historically been successful on the LTRI admissions exam, ${ }^{39}$ there was clearly a felt need to create new programs. Partly this probably reflected a view that having a JD program was important in order to maintain an existing undergraduate program (Maxeiner 2003, p. 11) which might be functioning as a profit center given the relatively low cost of delivering legal education. However, it is also likely that universities believed having such JD program was important for the public's perception of the institutions (or the faculty who taught in the existing undergraduate programs saw having a JD

\footnotetext{
${ }^{37}$ Based on a list found on Wikipedia, more than 60 institutions were rebranded as universities after 1992 (http://en.wikipedia.org/wiki/New_Universities\#Post-1992_universities that are_former_polytechnics, last visited February 22, 2012).

${ }^{38}$ Importantly, while the plan for the new law schools came from the Ministry of Justice and the Supreme Court, the administration of educational institutions falls under the authority of the Ministry of Education (Aronson 2012, p. 274). Arguably, the Ministry of Education was responsive to the demands from the universities, and allowed many more programs and places to be created than envisioned by the Ministry of Justice and Supreme Court when the latter institutions projected a 70 percent pass rate for the LTRI exam based on an assumption about the number of students who would study for the JD (Chan 2012, p. \{25-26\}).

${ }^{39}$ Five of the law schools produced two-thirds of the candidates who passed the exam (Maxeiner 2003, p. 10).
} 
program as important for their own status within the academy). A third likely consideration is that schools saw the new JD programs themselves as potential profit-centers. Some would probably argue that the most important factor was prestige. In post-war Japan, the undergraduate law faculties have been one of the most prestigious undergraduate faculties. Failing to create a JD programs could put the prestige that had accrued as a result of having an undergraduate law faculty at risk, perhaps in part by the new programs at other institutions attracting away top faculty. A fear of loss of prestige would create tremendous pressure to create a JD program.

One final consideration that explains the creation of at least some private law schools and one or more public programs in the U.S. is an institution's sense of mission. That is, the university starts a law school with the goal of turning out lawyers who will bring a particular perspective or approach to their future practices. As noted above, the University of St. Thomas expressed its reason for starting a law school in terms of a sense of mission. Most other law schools that would fall in this category are affiliated with religious movements or perspectives (Ave Maria Law School, Regents University Law School, Liberty University School of Law). The law school that was created in 1983 at the City University of New York had as its goal producing public interest lawyers (and it still describes itself as the "premier public interest law school in the country"). It may be the case that one or more private law schools in other countries were also established as expressions of a particular religious or political perspective.

One important development over the last twenty-five years is that the relative cost of starting a law school has declined. As noted above, the infrastructure that was in the past needed to create and maintain a law school was lecture halls and a library. For a new law school, the capital required to create the library needed by students was considerable because of the need to acquire a large quantity of printed materials in the form of case reports, law journals, and treatises. Today, a new law school can rely upon electronic resources for the bulk of what students will need for their studies. This also means that the amount and nature of physical space required for the library has changed; where once one would find crowds of students in the law library in the evening, the libraries today are largely deserted at night. While once the school needed to provide the facilities to access electronic materials in the form of computer labs and work stations, today students access the materials directly from their own laptops and tablets. Students still need spaces to meet to work in groups (often in the past provided by the law library) but creating such spaces is not as costly as creating and stocking a traditional law library. Law schools need to have librarians to assist students and faculty, subscriptions to online materials, and the infrastructure to access those materials in the form of wireless networks, but all of this is significantly different from the infrastructure needed a quarter century ago. 


\section{THE DEMAND SIDE}

\section{Choosing to Study Law}

One puzzle is the continued strong interest in studying law even in the face of evidence that likelihood of success in pursuing law as a career is either small or declining. The extreme example has long been Japan where the barriers to becoming a fully qualified legal professional, a bengoshi, have been formidable. The undergraduate faculties of law in Japan have long drawn many, many more students than could ever win a place at the Legal Training Institute; in fact, as a proportion of the population, the number of students studying law in Japan (ignoring the new post-graduate law schools) relative to the country's population greatly exceeds the comparable figure for those pursing JDs in the U.S. Through the 1980s, only about 500 persons per year passed the National Bar Examination in Japan (two to three percent of those taking the exam), although the number was increased to 1,500 by the mid-2000s (Yoshida 2006, p. 211). As discussed above, in 2004 Japan introduced post-graduate law schools. In 2011 those schools admitted 3,620 students (down from a peak of 5,800 in 2006 soon after the new law schools had started); ${ }^{40}$ but even with this more selective system, the pass rate of the new National Bar Examination in 2010 was only 25 percent, a total of 2,074 of the examinees (Tanikawa 2011). ${ }^{41}$ The drop in numbers of potential students seeking places in the JD programs probably reflects the reality that the bar exam has continued to be a major hurdle that blocks the majority from gaining entrance to the LTRI despite that fact that there was some expectation early on that as many as 70 percent of the graduates of the new JD programs would succeed on the exam. ${ }^{42}$

Anyone who has tried to introduce statistical or mathematical information in the typical American law school class has undoubtedly observed the glazing over of eyes among most of the students in the room. Of course there is a cadre of students for whom this is not an issue: those coming from an undergraduate degree in economics or accounting, or who had studied science or engineering. In countries such as England or Australia where law is a first degree, I suspect the response of students to such material would be even less enthusiastic. ${ }^{43}$ We often presume that the primary attraction of a career in law is financial, or possibly, service. Certainly law

\footnotetext{
${ }^{40}$ I have no figures on the admission rate to these schools, but if one assumes that most of those who start undergraduate law studies complete them, there would be about 40,000 law graduates each year, and only ten to fifteen percent of those are going on to study for a JD.

${ }^{41}$ In other words, about 8,300 persons took the exam which would be the equivalent of about two years output from the new law schools. Under the old system in Japan, there was no limit on the number of times a person could take the National Bar Exam. Under the new system, test-takers are limited to three attempts (Saegusa 2009, p. 393); after three unsuccessful attempts, one must reenroll and complete the JD course a second time, which apparently some people are seeking to do (Aronson 2012: 278). In 2011, 2,063 passed for a pass rate of 23.5\% (http://www.yomiuri.co.jp/dy/editorial/T110915004705.htm, last visited February 11, 2012).

42 As noted previously, the lower than expected pass rate also probably discouraged potential "returning students" (i.e., those who already were working in corporate settings) from pursuing JD degrees.

${ }^{43}$ This may in part accounts for the dearth of English law students who become interested in pursuing the empirical study of legal phenomena (see Genn, et al. 2006, p. 9-10).
} 
constitutes one of the occupations which carry a significant potential of prestige. ${ }^{44}$ There are, of course, other professional occupations that offer the potential of significant rewards and/or opportunities for service: medicine, accounting, architecture, engineering, various areas of information technology. However, law offers something these other fields generally lack: no apparent need to feel comfortable with mathematics. That is, most of the other "higher" professions require a level of comfort with mathematics that a significant proportion of people lack. Some might say that this makes the study of law "easier" than the courses of study associated with many other professional level occupations. Whether the study of law is in fact "easier" is questionable; it certainly is different with respect to mathematical content. ${ }^{45}$ More generally, law is a prestigious profession that does not require the same type of aptitude that is required for medicine and other science or math related professions (Tamanaha 2012a, p. 135).

One interesting possibility on the financial side that may make law attractive compared to medicine may be a perception in some countries that the income potential is greater in law than medicine. In countries such as Britain where healthcare provision is nationalized, most physicians work, or at least used to work, on a salaried basis and thus the income potential for the typical physician is limited. ${ }^{46}$ In contrast, those choosing a career in England regularly see news coverage reporting the very high fees earned by top solicitors and barristers. While only a few lawyers in England may have incomes along the lines of what gets highlighted in the press, those reports may create expectations that are very enticing to those making choices about possible careers. Someone recently told me half-jokingly that these days the ambitions of a Jewish parent in Britain is not for their son to become a doctor but rather to go into law because of the better financial prospects for a high-flyer in law.

\section{Financing Legal Education}

Central to the continued demand for legal education has been the combination of subsidy and the availability of financing (i.e., student loans). Generally, governments which provide the subsidy and the financing (or at least provide protections to financial institutions making student loans) have to date not been willing to impose limits which would impact demand. As noted

\footnotetext{
${ }^{44}$ The prestige of the legal profession does vary from country to country, and as discussed above with regard to Egypt, supra note 29, is potentially subject to some manipulation to political authorities who control educational institutions and their funding.

${ }^{45}$ Ironically, many people once they get into legal practice realize that some facility with mathematics is important for many areas of practice, and I suspect that many practitioners end up struggling to master some types of mathematical principles. I still puzzle over the student who took a course I offered entitled "Statistics for Lawyers," who told me that she really had trouble dealing with formulas and wanted to know how to express things in words. The puzzlement came when I learned that she wanted to specialize in tax law, and area that often involves understanding the implications of what can be complex tax formulas.

${ }^{46}$ Recent changes to the National Health Service have made most general practitioners private entrepreneurs whose income is dependent more on the quantity of patients served; those who can structure their practices to be efficient and serve large numbers can generate higher incomes.
} 
previously, direct government subsidies to public law schools in the U.S. have been declining in recent years, and this has shifted a greater portion of law school revenue to student loans. ${ }^{47}$ Moreover, as also noted previously the rise in tuition at both public and private law schools in the U.S. has been relentless, and has been sustained by students taking on an increasing amount of debt (Tamanaha 2012a, p. 109-11). The clear question is how long this can continue, particularly in light of the continuing effects of the economic crisis of 2007-08 which heavily impacted the job market for law graduates. One recent article spoke of the "law school bubble" (Henderson \& Zahorsky 2012) and another of "the coming crash in legal education” (Bourne 2012); both argued that the current system in the U.S. is not sustainable under current economic conditions (see also Tamanaha 2012b). The unknown is whether students will become less willing to take on substantial debt $(\$ 100,000$ to $\$ 200,000)$ given the uncertainties over job prospects (see the next section) or government will become less willing to provide the loan guarantees and subsidies. ${ }^{48}$ Importantly, Tamanaha has shown that the dependence on government loans (or government-guaranteed loans) is greatest for students who attend law schools where students have the least probability of being able to pay back those loans (Tamanaha 2012a, p. 154-55). ${ }^{49}$ He has suggested that the government should cap government student loans for each law school, end any government guarantee for private loans, and make private loans dischargeable in bankruptcy. The net effect of such changes would be to make the providers of private loans much more cautious and attentive to the likelihood of the loans being repaid. When combined with the cap on federal loans law schools would be forced to rationalize the size of their programs, to reduce costs, and to design programs that produce graduates who can repay the loans they receive (Tamanaha 2012b). ${ }^{50}$

As noted above, the number of students applying to Japan's new JD program has declined leading to a parallel decline in enrollments in those programs. While there has been no significant drop in total enrollments in American law schools so far, a decline may be starting. As shown in Figure $1,{ }^{51}$ the most recent two years have seen a drop in both the numbers taking

\footnotetext{
${ }^{47}$ Changes in England are producing a similar shift there.

${ }^{48}$ The average debt of graduates in 2008-09 was $\$ 100,002$ from those graduating from private law schools and $\$ 66,045$ for those graduating from public law schools (Bourne 2012, p. \{24\}). These figures represent a 42-43\% increase over the debt of those graduating in 2001-02. For 2011 graduates, the corresponding figures are \$125,000 and $\$ 75,700$ (Weiss 2012).

${ }^{49}$ Similarly, the average debt tends to be highest for graduates of those same schools (see Tamanaha 2012a, p. 11011,122-24). For example, the two schools with the highest average debt in 2011 were California Western and Thomas Jefferson, both of which had averages exceeding \$153,000 (Weiss 2012).

${ }^{50}$ Tamanaha also raises the possibility of applying to law schools the rule now applied to for-profit colleges whereby an institution loses its eligibility to receive funds from federal loans if a high proportion of graduates are unable to repay those loans.

${ }^{51}$ The sources for the data shown in figure 1 are the Law School Admissions Council (http://www.lsac.org/LSACResources/default.asp, last visited June 18, 2012) and the ABA Section on Legal Education and Admission to the Bar (http://www.americanbar.org/groups/legal_education/resources/statistics.html, last visited June 18, 2012). The figures for the number of applicants for the most recent year is an estimate based on information found at http://www.lsac.org/Members/Data/PDFs/Current-Volume-033012.pdf [last visited June 18,
} 
FIGURE 1: TRENDS RELATED TO AMERICAN LAW SCHOOLS

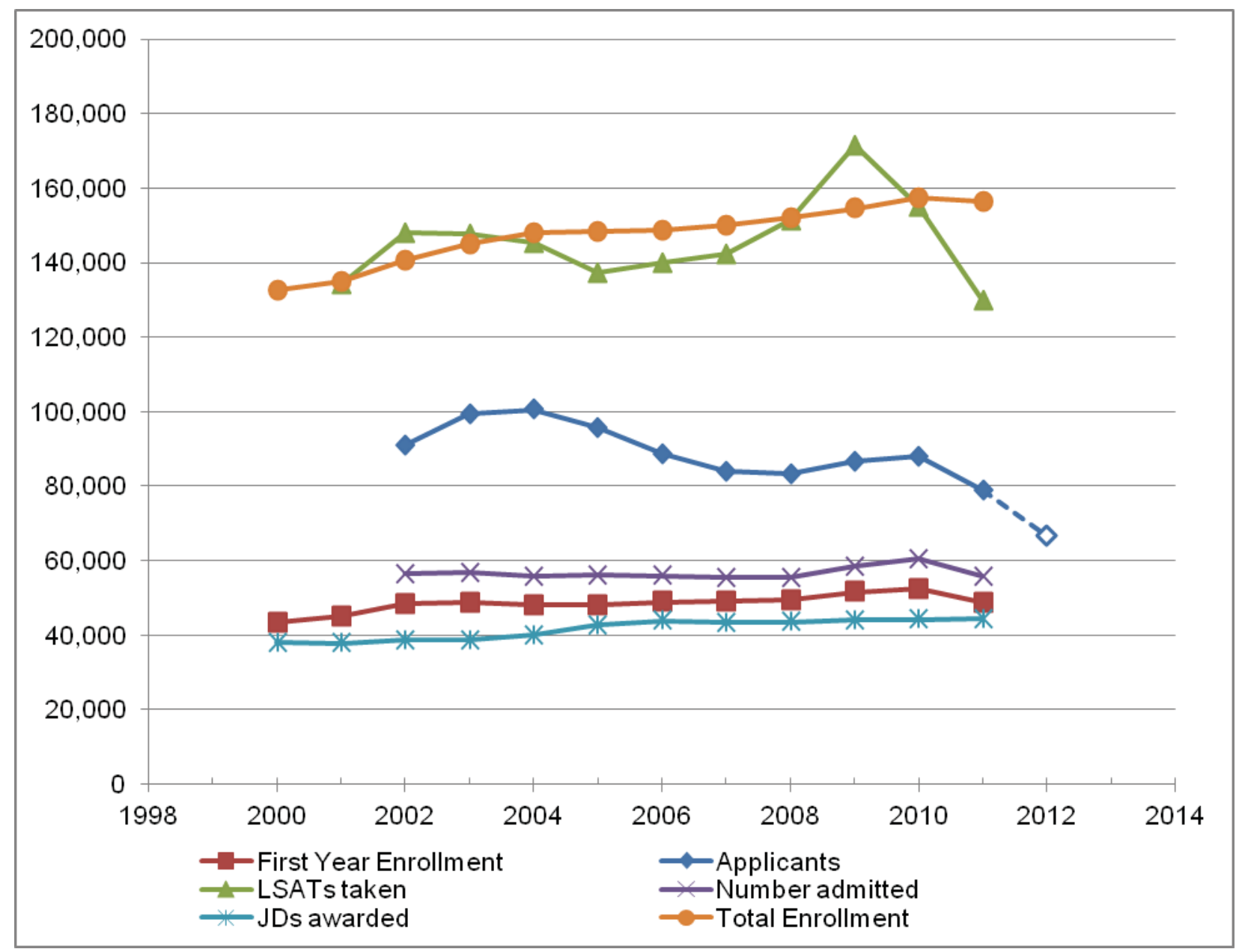

the Law School Admissions Test (LSAT) ${ }^{52}$ and the numbers applying to law school, and the 2011-12 academic year saw a drop of 7 percent in the number of entering JD students. ${ }^{53}$ However, as the figure also shows, there had been a pattern of decline in applicants since at least 2000. Until the most recent year, Figure 1 shows no drop in the number of students enrolling in law school or the number of graduates; only in the most recent year for which data are available is there a downturn in the number of students admitted and the number of students actually starting law school. Most likely the declines are not spread evenly across law schools, but rather are more concentrated in the lower ranked schools

2012]; the estimate assumes that 91 percent of applicants who will apply have apply at the time the data were compiled (which is the percentage the corresponds to the prior year's pattern).

52 Data are not yet complete for the 2011-12 cycle for LSAT administrations, but for the first three (of four) administrations, the number taking the LSAT is down about 17 percent (calculated from data at http://www.lsac.org/LSACResources/Data/lsats-administered.asp, last visited March 7, 2012).

${ }^{53}$ The drop in total law school enrollment was less than 1 percent, probably reflecting the increasing number of LLM students that American law schools are admitting (largely as a means of generating revenue). 
The importance of money provided through loans as the source of revenue for American law schools should not be underestimated. Almost 90 percent of law students borrow to finance their legal education (Bourne 2012, p. \{24\}). In 2010 American law students borrowed at least \$3.7 billion to finance their education (Henderson \& Zahorsky 2012, p. 32); this is over $\$ 25,000$ per law student (JD students only). If one takes the mean tuition of private law schools as the best estimate of the mean cost of legal education, money from loans constitutes over 70 percent of law schools' revenue..$^{54}$ In fact, this is probably an underestimate because the average tuition figure is based on "list prices" and do not take into account the heavy discounting that many law schools engage in to attract students; ${ }^{55}$ half or more of students at most schools pay less than list price (Bourne 2012, p. \{19\}). There are at least some law schools where tuition revenue is virtually 100 percent dependent on loans students obtain from the federal government. ${ }^{56} \mathrm{~A}$ sharp change in the amount of loan funds coming to the law schools would have a major impact. Such a potential change could reflect a shift in demand from students who might be less willing to take on debt given the job uncertainties or it could reflect a shift in supply of funds, either because government stops guaranteeing loans making private lenders more selective in their decisions about granting loans or because of a cut in government appropriations to cover loans coming directly from government agencies. Funds could also become scarce if repayments drop which in turn reduces the replenishment of funds available for future loans (Henderson \& Zahorsky 2012, p. 32).

Because of the government subsidy for legal education, the debt burden appears to have been considerably less in England than in the U.S. Only 20 percent of pupil barristers in 200910 reported having no educational debt; over half had debts of at least $£ 10,000$, and six percent owed more than $£ 40,000$ ('Further Drop in Pupillages' 2012). For trainee solicitors, the pattern (as of 2009) does not differ a great deal: 18 percent had no debt, 55 percent had debts of at least $£ 10,000$, and 35 percent had debts of more than $£ 15,000$ (Baksi 2010). This will all change with the new regime effective in September 2012 under which students will be borrowing from the government and then repaying based on income over a 30 year period. How this will impact the number of students pursuing a legal education and ultimately the number seeking to enter the profession will not be known for at least several years.

\footnotetext{
${ }^{54} \mathrm{My}$ figure of 70 percent ignores that fact that not all of the money loaned is paid to the law schools; some is used to cover living expenses. Living expenses can add 40 to 50 percent to the list price of tuition at a private law school located in a high cost city (Tamanaha 2012a, p. 99).

${ }^{55}$ While financial aid was once allocated on a need basis, today most discounting in American law schools is done to attract the students with the strongest metrics (LSAT scores and undergraduate GPAs) in order to enhance the law school's standing in the rankings published by US News \& World Report (Bourne 2012, p. \{18\}; Tamanaha 2012a, p. 97-98). The pressures over these metrics have resulted dubious practices (Segal 2011a) or even scandals where some schools have inflated their figures falsely to improve their standings in the rankings (see Sachdev 2011; Segal 2011b).

${ }^{56}$ ABA figures on the ratio of the total amounts of loans received by students to total tuition and fee revenue show many private schools having a ratio well over 1.0. If one assumes living expenses add 30-50 percent to a student's cost, total dependence would exist when the ratio is 1.3 or greater, and several private schools have such ratios. One cannot apply this calculation to public law schools because the state subsidy often means that students rely more on loans for living expenses than for the payment of tuition.
} 
It is likely that the debt issue is important in Japan, although I could find no published discussions (in English) of debt as a factor in legal education in Japan. As best I can tell based on correspondence with legal academics in Japan there are no government subsidies or loan guarantees for students attending the new JD law schools; students rely primarily on support from their families. Early on, when the expectation was that a high percentage of those earning JDs would pass the bar exam, it may have been the case that banks and other sources were willing to make loans to students on the expectation that there would be a low default rate; if that were the case, it has probably now changed given the experience with pass rates. Under the old system, most of those planning to take the bar exam attended cram schools which charged significant fees; there does not appear to have been any types of guarantees or subsidies (other than familial) for the vast majority attending those schools. One would expect that debt issues would loom fairly large in the Japanese context, but as noted above, I was not able to access any published discussions focused on this question.

\section{Changing Prospects for a Career in Law}

Not everyone who seeks a degree in law, whether an American-style post-graduate JD degree or the more common first degree (an LLB in most common law countries), seeks to obtain employment that requires a law degree. ${ }^{57}$ Nor is everyone completing formal training able to successfully pass required exams, or obtain a training contract, or find a job working as a legal professional. In the U.S., the best estimate is that 10 percent of those who attempt the bar exam never succeed in passing, and hence are unable to pursue a career as a lawyer (Yakowitz 2010, p. 3). Data from 20 years ago shows that about a quarter of law graduates were at that time not working as lawyers (or judges), with a quarter of those not in the workforce; most of the rest were working in nonlaw occupations, many in top and midlevel management positions (Baker \& Jorgensen 2000, p. 16). Presumably some significant portion were those who had not successfully passed the bar exam, with others either having never sought to enter practice and others have abandoned, at least temporarily, the profession either due to personal circumstances (e.g., family responsibilities) or after having failed in their efforts to make a go as a legal practitioner. More recently, the number of graduates of American law schools who are able to find employment as a lawyer has decreased, and the problem is inversely related to the ranking of the law school from which one obtains a degree (Tamanaha 2012a, p. 114-18).

For those whose primary goal is service, particularly in the sense of what has in the past been labeled as public interest law or legal aid type work, the prospects have long been problematic. First, and most important, the opportunities in this area are highly limited. The percentage of available positions in the public interest or legal aid arenas is small. In the United

\footnotetext{
${ }^{57}$ A likely exception here is those students in Japan who have enrolled in the new post-graduate law schools, but see Aronson (2012: 273-74) who suggests that some of those who pass the bar exam and complete the LTRI training course are having difficulty finding employment.
} 
States perhaps ten to fifteen percent of practitioners could be said to be working in these kinds of positions, and this figure includes all attorneys employed by government. Second, while many prospective lawyers express a desire to go into this kind of work, the financial realities of relatively low pay often work to deter graduates from pursuing that desire or staying in such work as the financial obligations mount (see Kahlenberg 1999). Third, the work can be very routine and clients are often not fully appreciative of their lawyer's effort (see Casper 1971; Hosticka 1979; McIntyre 1987). Lastly, much of the work involved in these kinds of positions lacks the significant intellectual component that makes legal practice interesting.

Recent research from the After-the-JD study shows that the most dissatisfied among U.S. law graduates in the first years of practice tend to be drawn from graduates of top level law schools, particularly graduates who come from upper middle class families (see Dinovitzer \& Garth 2007). A large proportion of these graduates have positions as associates in large law firms with salaries at or approaching the high end of what new JDs can hope to earn. However, this group finds the work itself, both the substance and the time demands, unsatisfying. That is, they may have both the income and prestige they might have sought, but they do not have the autonomy or interesting assignments they expected. The study finds that the most satisfied may be among those whose ambitions were modest, who attended a third or fourth tier law school, and for whom the status of even a lower level of practice without high income represents a step up from other opportunities they might have. Importantly this study is following lawyers who completed law school in 2001; given the combination of the sharp rise in the debt burden of law school graduates (due in significant part to ever rising tuition) and the reduced job prospects of many graduates (both in terms of actual employment and potential salary), recent graduates of those lower ranked schools may face a particularly harsh job market while carrying a heavy debt burden (see Tamanaha 2012a, p. 110,118).

Importantly, while American JDs who had service as a primary goal have long had difficulty finding positions that fulfill that ambition, the economic downturn has created difficulties for the other groups as well. Law firms large and small (and medium) have reduced hiring (Bourne 2012, p. \{9-11\}); firms have shed both associates and partners. The large corporate law firms may change their hiring strategies to focus on a smaller number of schools as "suppliers" (see Furlong 2012). While American law schools continue to turn out about 45,000 new JDs each year, projections suggest that the job market will produce only about 25,000 openings per year for those graduates through 2018 (Tamanaha 2012a, p. 139). The result is that finding a job after graduation is now a challenge for a much larger proportion of law graduates, and will continue to be a challenge, at least until a significant number of baby boomers now in practice choose to retire. The amount that has now been written about this issue (see, for example, Koppel 2011; Lowrey 2010; Segal 2011b; Sloan 2010) has likely sensitized many potential law students to the difficulties they may face and this may account for the decline in applications and LSAT-takers. However, while most commentators seem to be pessimistic, only time will tell whether either the 
worsened job prospects of law graduates or the apparent decline in interest in attending law school represents more than temporary phenomena.

What about other countries? As discussed above, demand for the JD programs in Japan has clearly dropped as it has become evident that the prospects of success on the new bar exam continue to be dim (although not anywhere as near as dim as was the case under the pre-JD system). In Ontario (the only province of Canada for which I have been able to find data for more than a few years), the number of applicants has, with the exception of one year, risen steadily over the last decade (see http://www.ouac.on.ca/statistics/law-school-applicationstatistics/, last visited March 7, 2012). ${ }^{58}$ The last year has seem some discussion of an "articling crisis" in Ontario which refers to the problem a small portion (12 percent in 2011) of law graduates being unable to secure 10-month positions as articled clerks which is a requirement to qualify for practice (Gray 2011); in part this probably reflects that the number seeking such positions increased 25 percent between 2006 and 2010 (McKiernan 2011). ${ }^{59}$ In England it has long been the case that a significant number of those completing the legal practice course (LPC), which is the one-year post-LLB course required for those hoping to enter practice as solicitors, have encountered difficulties in securing traineeship positions (what were once called "articles" in England); those difficulties appear to be increasing. In part this reflects that there are many more places in the LPC $(14,482)$ and many more students enrolled in the course $(9,337$ in 2010) than there are available training contracts (5,809 in 2010). ${ }^{60}$ Moreover, the government cut funding that provided positions for 750 traineeships for potential legal aid solicitors (Rose 2010). It is important to note that the hunt for training contracts does not end if one is not secured the first year; this means that the number actually seeking such contracts is considerably greater than the number successfully completing the LPC each year (Nair 2011). On the barristers' side of the profession, the number of pupilages declined about 20 percent between 2007-08 and 2010-11 ('Further Drop in Pupillages' 2012).

\section{CONCLUSION}

How will law schools and law students respond to the potential financial challenges and the changing career prospects that either have developed or appear to be on the horizon? Will many of those who looked to study law turn to other pursuits in light of growth in the cost of legal

\footnotetext{
${ }^{58}$ The Law School Admission Council, which handles applications to Canadian law schools as well as U.S. law schools, has released some information on the number of Canadian applicants over the last three years. Interestingly, the drop-off in U.S. applications has not been experienced in Canada (see

http://www.lsac.org/LSACResources/Data/three-year-volume.asp, last visited June 20, 2012).

${ }^{59}$ There is also some indication that those completing their articling requirement are having trouble finding permanent positions. According to survey data, the percentage hired by the firms where they articled dropped from 52 percent in 2005 to 43 percent in 2010; over that same period the percentage who had found jobs by the time they were called to the bar dropped from 66 percent to 551/2 percent (McKiernan 2011).

${ }^{60}$ Rose notes that the number of LPC places increased by 70 percent between 2000 and 2010 while the number of training contracts for those completing the course increased by only 20 percent.
} 
education and the dimmed prospect of a lucrative career? If applications to law schools continue to drop, will law schools seek to maintain their current level of enrollments or adjust their size (and budgets) to reflect the changed market for the education they deliver? Will alternative methods of delivering legal education at a lower cost (and hence imposing lower burdens and risks on students) become an important factor (see Tamanaha 2012a, p. 172-77)? What, if any, impact will any of these changes should they occur have on the number of lawyers offering their services to the public?

The current momentum, both in terms of demand and supply may be difficult to slow. There are too many interests that have a stake in the system as it now exists. While one might expect major changes in demand, one could also speculate that the types of persons who choose to pursue legal education are less sensitive to the risks than the average student might be. In his recent book, Thinking, Fast and Slow, Daniel Kahneman (2011, p. 256-58) describes what he labels "entrepreneurial delusion" by which he means the "optimistic temperament" possessed by many entrepreneurs who grossly overestimate the likelihood that their new businesses will be successful (about two-thirds of new small businesses in the U.S. fail within the first five years). It may be that those who choose to pursue law degrees suffer from what one might label "career delusions": they know that a significant number of law graduates encounter trouble in launching a professional career, but they believe they are different. ${ }^{61}$ In the context of the American law school, I suspect that few if any students expect that their performance in school will place them in the lower half of their graduating class, even though by definition half of the graduates must be in the lower half, and ten percent must be in the bottom decile! Students who are unwilling to ask about the chances of success because they believe they cannot do anything but succeed, are unlikely to back off from pursuing a legal education. If this is true, the growth of the legal profession is likely to continue in the absence of externally imposed controls.

Countries such as Japan and Korea that have long had rigid controls may be allowing some growth in the number of fully qualified lawyers, but that growth in terms of absolute numbers is modest and there is no indication that it will be anything but modest even when there has been much discussion about the need for significant growth. Where such controls have not existed it is likely to be politically difficult to impose them. For example, in the 1990s the Law Society in England sought to freeze the number of positions available in the legal practice course (LPC) in order to deal with the bottleneck would-be solicitors faced in obtaining training contracts;

${ }^{61}$ Segal (2011b) reports, "Independent surveys find that most law students would enroll even if they knew that only a tiny number of them would wind up with six-figure salaries. Nearly all of them, it seems, are convinced that they're going to win the ring toss at this carnival and bring home the stuffed bear.” Tamanaha (2012a, p. 143-44) describes this “optimism bias” in the following way: "Law students are high achievers, accustomed to doing well with effort. They assume that this reliable path to past success will pay off again without fully realizing - until they sit in the class and look around - that everyone else in the room is just as smart and hard working. Only after arrival do the long odds of success sink in-and then it is too late.” 
however it backed down when providers of the LPC threatened legal action over the anticompetitive impact of any such limits (Rose 2010). In other words, the economic interest of the providers of legal education trumped the interest of the professional body.

\section{REFERENCES}

ABEL, R. L. (1986) The Decline of Professionalism, Modern Law Review 49: 1-41.

ABEL, R. L. (1988) The Legal Profession in England and Wales (Oxford, Basil Blackwell).

AHN, K. W. (2006) Law Reform in Korea and the Agenda of 'Graduate Law School', Wisconsin International Law Journal 24(1): 223-242.

ARONSON, B. (2012) The Brave New World of Lawyers in Japan Revisited: Proceedings of a Panel Discussion on the Japanese Legal Profession After the 2008 Financial Crisis and the 2011 Tohoku Earthquake, Pacific Rim Law \& Policy Journal 21: 255-294 [http://papers.ssrn.com/sol3/papers.cfm?abstract_id=1904556].

BAKER, J. G. \& JORGENSEN, B. K. (2000) Leaving the Law: Occupational and Career Mobility of Law School Graduates, Journal of Legal Education 50(1): 16-34.

BAKSI, C. (2010) Trainee Solicitors Fact Debts of More than £10,000, Law Society Gazette [http://www.lawgazette.co.uk/news/trainee-solicitors-face-debts-more-10000].

BOURNE, R. W. (2012) The Coming Crash in Legal Education: How We Got Here, and Where We Go Now, Creighton Law Review 45(4): xx-yy [http://ssrn.com/paper=1989114].

BRUSEGARD, D. (2004) The Implications of Demographic Change in the Legal Profession (Ottawa, Canadian Bar Association) [http://www.cba.org/cba/futures/pdf/demographics_feb04.pdf].

CASPER, J. D. (1971) "Did You Have a Lawyer When You Went to Court? No, I Had a Public Defender.", Yale Review of Law and Social Action 1: 4-9.

CHAN, K.-W. (2012) Setting the Limits: Who Controls the Size of the Legal Profession in Japan, TBA.

CLARK, D. S. (2012) Legal Education, in D. S. CLARK (ed) Legal Education (Cheltenham, UK, Edward Elgar Publishing).

COHEN, D. S. (1998) How Many Lawyers and Law Students? The Supply of Lawyers in Canada BarTalk [http://www.cba.org/bc/bartalk_95_00/08_98/guest_cohen.aspx].

DINOVITZER, R. \& GARTH, B. G. (2007) Lawyer Satisfaction in the Process of Structuring Legal Careers, Law \& Society Review 41(1 \%R doi:10.1111/j.1540-5893.2007.00290.x): 1-50 [http://www.blackwell-synergy.com/doi/abs/10.1111/j.1540-5893.2007.00290.x ]. 
DODEK, A. (2011) An Education and Apprenticeship in Civility: Correspondent's Report from Canada, Legal Ethics 14(2): 239-245.

ERLANGER, H. S. \& KLEGONN, D. A. (1978) Socialization Effects of Professional School: The Law School Experience and Student Orientations to Public Interest Concerns, Law \& Society Review 13: 11.

FISCHER, H. (2010) ASU's Law School Moves to Privatize, [http://www.azcentral.com/business/abg/articles/2010/11/04/20101104abglawschools1104.html].

FOOTE, D. H. (2011) Internationalization and Integration of Doctric, Skills and Ethics in Legal Education: The Contrasting Situations of the United States and Japan, 有斐閣 [The Sociology of Law] 75: 8-70.

FURLONG, J. (2012) Why Are You Recruiting?, JDSUPRA) [http://www.jdsupra.com/post/documentViewer.aspx?fid=d6f42bb1-04e1-459c-8277d12ce18508c8].

'Further Drop in Pupillages' (2012), Solicitors Journal (January 24): 5.

GENN, H., PARTINGTON, M. \& WHEELER, S. (2006) Law in the Real World: Improving Our Understanding of How Law Works, Final Report and Recommendations (London, Nuffield Foundation).

GRAY, J. (2011) 'Law Profession Faces an 'Articling Crisis", Globe and Mail (November 2) [http://www.theglobeandmail.com/report-on-business/industry-news/the-law-page/lawprofession-faces-an-articling-crisis/article2221786/].

HENDERSON, W. D. \& ZAHORSKY, R. M. (2012) The Law School Bubble, ABA Journal 98(1): 30-35.

HOSTICKA, C. J. (1979) We Don't Care About What Happened, We Only Care About What is Going to Happen: Lawyer-Client Negotiations of Reality, Social Problems 26: 599-610.

HUTTON, W. ( 2012) 'How Will £9,000 Tuition Fees Affect Students? We'll Be Finding Out', Guardian (January 27) [http://www.guardian.co.uk/commentisfree/2012/jan/27/how-will-tuitionfees-affect-students].

JONES, C. P. A. (2009) Japan's New Law Schools: The Story So Far, Zeitschrift für Japanischesrecht/Journal of Japanese Law(27): 249-256.

KAHLENBERG, R. D. (1999) Broken Contract: A Memoir of Harvard Law School (Amherst, University of Massachusetts Press).

KAHNEMAN, D. (2011) Thinking, Fast and Slow (New York, Farrar, Straus and Giroux).

KIBBLE, N. (1989) Access to Legal Education and the Legal Professions in England, in R. DHAVAN, N. KIBBLE \& W. TWINING (eds) Access to Legal Education and the Legal Profession (London, Butterworths).

KIM, C. R. (2006) The National Bar Examination in Korea, Wisconsin International Law Journal 24(1): 243-260. 
KOPPEL, N. (2011) 'Law School Loses Its Allure as Jobs at Firms Are Scarce', Wall Street Journal (Online) (March 16).

KORIOTH, S. (2006) Legal Education in Germany Today, Wisconsin International Law Journal 24(1): 85-107.

KRITZER, H. M. (1991) Abel and the Professional Project: The Institutional Analysis of the Legal Profession, Law \& Social Inquiry 16: 529-552.

LEVIN, A. \& ALKOBY, A. (2012) Is Access to the Profession Access to Justice? Lessons from Canada, TBA.

LOWREY, A. (2010) 'How Law School Went from Being a Sure Thing to a Bum Deal', Washington Post (October 31).

MAXEINER, J. R. (2003) The New Japanese Law Schools (Kansas City, MO, University of Missouri Kansas City)

[http://law.bepress.com/cgi/viewcontent.cgi?article=1183\&context=expresso].

MAZER, B. M. (1989) Access to Legal Education and the Profession in Canada, in R.

DHAVAN, N. KIBBLE \& W. TWINING (eds) Access to Legal Education and the Legal

Profession (London, Butterworths).

MCINTYRE, L. (1987) The Public Defender: The Practice of Law in the Shadows of Repute (Chicago, University of Chicago Press).

MCKIERNAN, M. (2011) 'Articling Crisis Set to Grow: Stats Show Jobless Candidates Double as Law Schools Expand', Law Times (June 6)

[http://www.lawtimesnews.com/201106068480/Headline-News/Articling-crisis-set-to-grow].

MOODIE, G. (2010) Trends, Risks and Opportunities in Australian Higher Education Post 2012 University of New England Cuncil Retreat (Abington, Bundarra, NSW

[http://www.une.edu.au/governance/academicboard/Occasional\%20Addresses/gavinmoodie.pdf].

MOUSTAFA, T. (2010) The Islamist Trend in Egyptian Law, Politics and Religon 3: 610-630.

NAIR, K. (2011) The Hunt for the Legal Training Contract: Advice for Law Graduates Guardian Careers Blog.

OGLOFF, J. R. P., LYON, D. R., DOUGLAS, K. S. \& ROSE, V. G. (2000) More Than 'Learning to Think Like a Lawyer:' The Empirical Research on Legal Education, Creighton Law Review 34: 73-243.

PIÑEIRO, L. B. (2012) Legal Education in Spain: Challenges and Risks on Devising Access to Legal Professions, TBA.

PRIOR, L. (2008) The Pinstriped Prison (Sydney, Macmillan Australia).

ROSE, N. (2010) 'Legal Training System Failing Law Law Students', Guardian [http://www.guardian.co.uk/law/2010/jul/13/legal-training-law-students].

SACHDEV, A. (2011) 'U. of I. Law School under Review for False Admissions Data', Chciago Tribune (October 7) [http://articles.chicagotribune.com/2011-10-07/business/ct-biz-1007chicago-law-20111007_1_law-school-admission-test-american-bar-association-law-students]. 
SAEGUSA, M. (2009) Why the Japanese Law School System Was Established: Co-optation as a Defensive Tactic in the Face of Global Pressures, Law \& Social Inquiry 34(2): 365-398 [http://dx.doi.org/10.1111/j.1747-4469.2009.01150.x].

SEGAL, D. (2011a) 'Is Law a Losing Game?', New York Times (January 8, 2011) [http://www.nytimes.com/2011/01/09/business/09law.html].

SEGAL, D. (2011b) 'Is Law School a Losing Game?', New York Times (January 9, 2011) [http://www.nytimes.com/2011/01/09/business/09law.html?pagewanted=all].

SEGAL, D. (2011c) 'Law School Economics: K-Ching', New York Times (July 16, 2011).

SLOAN, K. (2010) 'What Are They Thinking? Law School Applications Are Increasing Despite Dark Careeer Prospects', National Law Journal (July 12): 1.

STOVER, R. V. (1989) Making It and Breaking It: The Fate of Public Interest Commitment During Law School (Urbana, IL, University of Illinois Press).

TAMANAHA, B. Z. (2012a) Failing Law Schools (Chicago, University of Chicago Press).

TAMANAHA, B. Z. (2012b) 'How to Make Law School Affordable', New York Times (June 1): 23.

TANIKAWA, M. (2011) 'A Japanese Legal Exam That Sets the Bar High', New York Times (July 10).

WARING, P. J. S. (1995) Legal Education: An Inquiry into Demographics and Motivatins of Students Entering Law School Adult Continuing Education, Unpublished Doctoral Thesis (DeKalb, Illinois, Northern Illinois University ).

WEISBROT, D. (1989) Access to Legal Education in Australia, in R. DHAVAN, N. KIBBLE \& W. TWINING (eds) Access to Legal Education and the Legal Profession (London, Butterworths).

WEISS, D. C. (2011) Think the Bar Exam Is Tough? Be Thankful You Don't Live in Japan, ABA Journal

[http://www.abajournal.com/news/article/think_the_bar_exam_is_tough_be_thankful_you_dont live_in_japan/].

WEISS, D. C. (2012) Average Debt of Private Law Schoo Grads is \$125k; It's Highest at These Five Schools, ABA Journal

[http://www.abajournal.com/news/article/average_debt_load_of_private_law_grads_is_125k_the se_five_schools_lead_to_m].

YAKOWITZ, J. (2010) Marooned: An Empirical Investigation of Law School Graduates Who Fail the Bar Exam, Journal of Legal Education 60(1): 3-40.

YOSHIDA, K. (2006) Legal Education Reforms in Japan: Background, Rationale, and the Goals to be Achieved, Wisconsin International Law Journal 24(1): 209-222. 